1 Cleator, I G M, and Christie, J, British fournal of Surgery, 1973, 60, 163.

2 Shaffer, R D, Archives of Surgery, 1969, 99, 542.

${ }^{3}$ Steinberg, D M, Cooke, W T, and Alexander-Williams, J, Gut, 1973, 14, 865.

4 Painter, N S, British Medical fournal, 1968, 3, 475.

5 McEwan, A J, British fournal of Urology, 1968, 40, 350.

6 Hoare, E M, British fournal of Surgery, 1973, 60, 407.

7 Nicell, P, et al, Surgery, 1975, 78, 555.

8 Bevan, P G, British Medical fournal, 1961, 1, 400.

${ }^{9}$ Monro, J L, et al, British Fournal of Surgery, 1974, 61, 445.

10 Barrett, N R, Thorax, 1946, 1, 48.

11 Bradbrook, R A, British fournal of Surgery, 1973, 60, 331.

12 Sheil, A G R, et al, British fournal of Surgery, 1969, 56, 840.

13 Bigge, T, and Rothnie, N G, British Fournal of Surgery, 1974, 61, 545.

14 Prakash, A, Sharma, L K, and Pandit, P N, British fournal of Surgery, $1974,61,162$

\section{Bundle branch block in acute myocardial infarction}

Bundle branch block has long been known to carry a poor prognosis in acute myocardial infarction. ${ }^{1}$ As we have come to know more about the morphology of the conduction system of the heart there have been further inquiries into the problem. Sudden death is frequent in these patients, either during the acute phase or later, ${ }^{23}$ and at first sight it might seem possible to prevent some of these fatalities by using artificial pacemakers.

After an acute myocardial infarction conduction defects affect the prognosis to a variable degree. Many patients with severe conduction abnormalities appear clinically well until disaster strikes. Left bundle branch block is associated with a mortality of about $50 \%, 4-6$ but it is less widely recognised that right bundle branch block is equally ominous. ${ }^{4}$ The highest mortality is linked with defects affecting both bundles. Several varieties occur, the most common being right bundle branch block with left anterior hemiblock, but all may produce mortality rates as high as $70 \% .{ }^{78}$ On the other hand, the presence of a lone hemiblock is relatively benign and does not appear to influence mortality ${ }^{9}$ appreciably.

While there is often a progressive impairment of conduction culminating in complete heart block, the most frequent cause of death lies in the nature of the infarct itself. Widespread conduction disturbances are usually produced by extensive infarction, and death occurs because of the large-scale muscle damage rather than the accompanying conduction defect, though the mode of death may be asystole. In a few patients damage may be more localised, and then the onset of complete heart block or ventricular asystole may cause death. Recently it has been emphasised that left bundle branch block may indicate an increased susceptibility to ventricular arrythmias. ${ }^{10}$

Not surprisingly, therefore, prophylactic temporary pacing has had little effect on the death rate in these patients. ${ }^{41}$ Individual patients with selective destruction of conduction tissue may benefit from pacing, but their recognition is difficult. Opinion is divided on whether it is better to insert a pacing catheter prophylactically in patients with bundle branch block or to await the development of complete heart block before taking action. ${ }^{6}{ }^{11}$ Bundle of His recordings may help identify patients at high risk of developing A-V block. ${ }^{12}$

The problem of late sudden deaths has prompted claims that patients who have evidence of bilateral bundle branch block, especially if complicated by transient A-V block in the acute phase, derive benefit from permanent pacemaker implantation. ${ }^{2} 3$ So far few patients have been studied, however, and it is still uncertain how many of these late deaths are due to asystole; ventricular tachycardia or fibrillation might equally be the cause.

It seems, then, that the appearance of bundle branch block in a patient with an acute infarction carries a serious prognosis. After the development of complete heart block temporary pacing is of limited value but should certainly be attempted. Prophylactic pacemaker insertion has not yet been shown to be of definite value, and further randomised prospective trials of this treatment seem indicated in high-risk patients. Longterm pacing is a more formidable problem, and there is still little convincing evidence of its worth. Further investigation of the cause of late deaths seems desirable. Permanent pacemaker implantation, which might not be helpful and would certainly be very costly, is indicated at present only as part of a controlled clinical trial.

${ }^{1}$ Master, A M, Dack, S, and Jaffe, H L, American Heart fournal, 1938, 16, 283.

2 Atkins, J M, et al, New England fournal of Medicine, 1973, 288, 281.

3 Waugh, R A, et al, Circulation, 1973, 47, 765.

4 Godman, M J, Lassers, B W, and Julian, D G, New England Fournal of Medicine, 1970, 282, 237.

${ }^{5}$ Hunt, D, and Sloman, G, British Medical fournal, 1969, 1, 85.

${ }^{6}$ Scheinman, M, and Brenman, B, Circulation, 1972, 46, 753.

7 Godman, M J, Alpert, B A, and Julian, D G, Lancet, 1971, 2, 345.

${ }^{8}$ Roos, J C, and Dunning, A J, British Heart fournal, 1970, 32, 847.

Kincaid, D T, and Botti, R E, American fournal of Cardiology, 1972, 30, 797.

${ }^{10}$ Scheidt, S, and Killip, T, fournal of the American Medical Association, 1972, 222, 919.

11 Nimetz, A A, et al, American Heart fournal, 1975, 90, 439.

12 Lie, K I, et al, Circulation, 1974, 50, 935.

\section{Breaking down sex barriers}

There was a time, and that not too long ago, when the metaphorical wall separating the sexes in our mental hospitals was as effective as the physical wall separating East and West Berlin. The penalties for breaching either wall were dire. But it was not always so. For example, the history of Friern Hospital $^{1}$ (better known perhaps by its original name, Colney Hatch Asylum) records that in 1856600 patients of both sexes dined daily in harmony in the large "exercising hall." This exemplified the mood of liberalism then prevailing, which found expression in the Asylum Committee's report of 1859: "The more freedom which can with propriety be allowed them [the patients] and the more confidence reposed in them the better it will be for themselves and those whose duty it is to watch over them." That brave new world, for reasons undisclosed, collapsed in a heap; and the history sadly records that by the end of the century all patients were back eating in their wards.

The whirligig of time brings in its revenges, however, and midway through the present century-at first slowly, and thereafter with ever increasing speed-the wall separating the sexes began to crumble to a point where today only vestigial remnants are to be seen. With considerable trepidation female staff had been introduced into male wards and later, with even greater trepidation, male nurses introduced into female wards. In both instances the initial attendant fears generally proved unjustified. Then, as an extension of the same basic principle, mixed wards were established, and these are now a commonplace in many progressive mental hospitals in Britain.

Accounts of this recent revolution in the philosophy and in the practice of operating mixed-sex wards have been relatively scanty, so that a detailed description ${ }^{2}$ from New Zealand, 